\title{
The management of orthotropic stems modulates the photosynthetic performance and biomass allocation of productive plants of Arabica coffee ${ }^{1}$
}

\author{
Tafarel Victor Colodetti ${ }^{2 *} \mathbb{D}$, Wagner Nunes Rodrigues², Sebastião Vinícius Batista Brinate ${ }^{2}$ \\ Lima Deleon Martins ${ }^{2,3}$, Paulo Cezar Cavatte ${ }^{4}$, Marcelo Antonio Tomaz
}

$10.1590 / 0034-737 X 202067060005$

\begin{abstract}
Due to the possibility of enhancing the physiological responses by modulating the architecture of coffee trees, the objective of the study was to analyze the leaf gas exchanges and biomass allocation of Arabica coffee cultivated with different numbers of orthotropic stems. The experiment was carried out in a plantation located in Santa Teresa-ES, Brazil, cultivated with spacing of $2.5 \times 1.0 \mathrm{~m}$, using the cultivar Catuaí Vermelho IAC44. The gas exchange rates were monitored along stages of the phenological cycle (2014/2015), following a split-plot scheme, $3 \times 3$ (number of orthotropic stems per plant in three levels: 1, 2 and 3; and the phenological stages in three levels: flowering, fruit formation and maturation). The allocation of biomass in the plagiotropic branches was also analyzed during the phenological stage of fruit maturation. The management of the number of orthotropic stems affected the photosynthetic responses and biomass allocation of coffee trees. Under the studied conditions, cultivating the plants with two orthotropic stems created conditions which promoted the photosynthetic responses. Keeping more stems promotes the availability of leaves per amount of produced fruits in the plagiotropic branches, allowing the plant to sustain the production with less metabolic wearing.
\end{abstract}

Keywords: Coffea arabica; gas exchange; dry matter; management; pruning.

\section{INTRODUCTION}

Recent studies have been exploring alternatives to manage the growth of orthotropic stems (vertical stems) of plants of Arabica coffee (Coffea arabica L.) and have been achieving promising results (Verdin Filho et al., 2016; Colodetti et al., 2018). Previous results suggested gains for agribusiness due to decreasing the manpower required at harvest, increasing crop yield and decreasing biennial effects (Verdin Filho et al., 2016). In addition to changes in the canopy architecture with gains in crop yield and proportion of large grains (Colodetti et al., 2018).

A plantation of Arabica coffee is considered efficient when the plants are able to continuously form an extensive canopy system, which allows adequate penetration of sunlight and enhance the photosynthetic rates, making it possible to sustain the fruit growth to achieve higher crop yields. Gains in productivity can be observed in crops subject to densification, in addition to the possibility of decreasing production costs, enhancing land use, increasing the light use efficiency, promoting the exploration of the soil and increasing the capacity to absorb water and nutrients (Carvalho et al., 2006).

The crop densification is based on the increase of the number of plants per area, often making possible, along with a set of other technologies, to achieve considerable increases in productivity. Rodrigues et al. (2016) reported divergent responses in Arabica coffee genotypes cultivated under denser conditions, where different cultivars showed high levels of crop yield, lower biennial effects, biometric changes, among other positive

\footnotetext{
Submitted on May $20^{\text {th }}, 2020$ and accepted on August $17^{\text {th }}, 2020$.

${ }^{1}$ This work is part of the first author's Masters Dissertation, funded by CAPES

${ }^{2}$ Universidade Federal do Espírito Santo, Centro de Ciências Agrárias e Engenharias, Programa de Pós-Graduação em Produção Vegetal, Alegre, Espírito Santo, Brazil. tafarelcolodetti@hotmail.com,wagnernunes@outlook.com, brinatesvb@gmail.com

${ }^{3}$ Centro Universitário São Camilo, Departamento de Engenharia, Cachoeiro de Itapemirim, Espírito Santo, Brazil. limadeleon@saocamilo-es.br

${ }^{4}$ Universidade Federal do Espírito Santo, Centro de Ciências Agrárias e Engenharias, Departamento de Biologia, Alegre, Espírito Santo, Brazil. cavattepc@hotmail.com

Universidade Federal do Espírito Santo, Centro de Ciências Agrárias e Engenharias, Departamento de Agronomia, Alegre, Espírito Santo, Brazil. marcelo.tomaz@ufes.br

*Corresponding author: tafarelcolodetti@ hotmail.com
}

Rev. Ceres, Viçosa, v. 67, n.6, p. 454-463, nov/dec, 2020 
agronomic characteristics. Beside the alteration of the plant spacing, it is also possible to increase the crop density by increasing the number of orthotropic stems per plant.

Important considerations should also be raised regarding the effects of pruning on Arabica coffee plants, since the ability to change the source/drain relation for carbohydrates can be used to promote the canopy renewal and, therefore, in the rejuvenation of the photosynthetic apparatus (Pereira et al., 2013). If used correctly, the pruning can favor the formation of new branches and leaves, which will act directly on the physiological metabolism of plants. The pruning helps establishing control over the vegetative growth, as well as increasing the luminosity and aeration inside the canopy (Sartori et al., 2007).

The search for less expensive ways to manage coffee crops; in order to explore better the resources and improve physiological, biometric and productive traits of the plants; is considerably beneficial to the productive system, contributing to the sustainability of the activity. In this context, the cultivation of Arabica coffee using more than one orthotropic stem per plant is still an important research object. Scientific data is still incipient regarding the morpho-physiologic response of plants to this technique. For this, the objective of this study was to analyze the leaf gas exchange rates and biomass allocation of Arabica coffee plants cultivated with different numbers of orthotropic stems.

\section{MATERIALAND METHODS}

\section{Characterization of the experimental field}

The experiment was developed in a cultivation field, located in the municipality of Santa Teresa, in the mountainous region of the Espírito Santo state. The altitude of the site is $740 \mathrm{~m}$ and the soil is classified as a redyellow Oxisol. The region presents wavy-rugged topography, with an average annual rainfall of 1,282 $\mathrm{mm}$ and average annual temperature of $21.1^{\circ} \mathrm{C}$. June is the driest month of the year, while the wettest month is December. January is the hottest month of the year, averaging $23.7^{\circ} \mathrm{C}$. June is the coldest month, averaging $18.5^{\circ} \mathrm{C}$. The region is located in a zone classified as apt for the cultivation of Arabica coffee (Pezzopane et al., 2012).

The plantation where the experiment was implemented underwent a low-cut pruning in 2012, and the new shoots were conducted in order to promote the establishment of the desired number of orthotropic stems for each experimental plot. The spacing of the crop was standardized at $2.5 \times 1.0 \mathrm{~m}$. The cultivar used was Catuaí Vermelho IAC44, which is widely used in Brazilian coffee plantations. The fertilization management was carried out according to the recommendations for Arabica coffee in the Espírito Santo state (Prezotti et al., 2007), as well as phytosanitary treatments and cultural practices (Reis \& Cunha, 2010). The plants were cultivated in rainfed system.

\section{Analyses of photosynthetic characteristics}

Chlorophyll indexes and gas exchange rates were monitored in the coffee plants along the phenological stages of the reproductive cycle (flowering, fruit formation and maturation of fruits) (Camargo \& Camargo, 2001). For this end, the experiment followed a split-plot (in time) design, with number of orthotropic stems per plant at three levels (1, 2 and 3 orthotropic stems) in the parcels, and phenological phases at three levels (flowering, fruit formation and maturation of fruits) in the sub-parcels. The experimental plots were composed of three plants in line, and were distributed in a randomized block design, with eight repetitions.

The evaluations occurred in the year 2015, during the first productive cycle after the establishment of the treatments. From each plant of the plot, two average plagiotropic branches were selected, marked and identified to carry out the evaluations throughout the cycle.

All the measurements were taken in sunny mornings, between 8:00 and 11:00 hours, on two leaves of each assigned branch. The leaves were selected between the third and fourth pair of leaves from the apex of the plagiotropic branch, sampling fully expanded leaves, completely mature and without visual signs of occurrence of any kind of anomaly.

The chlorophyll $a$ index, chlorophyll $b$ index, total chlorophyll index and ratio of chlorophylls $a / b$ were evaluated using a portable chlorophyll-meter (ClorofiLOG FL1030, Falker). The leaf gas exchange rates were evaluated to estimate the photosynthetic variables, using a portable infrared gas analyzer (IRGA 6400XT, Licor) to study the net photosynthetic rate of $\mathrm{CO}_{2}\left(A, \mu \mathrm{mol} \mathrm{CO} \mathrm{m}^{-}\right.$

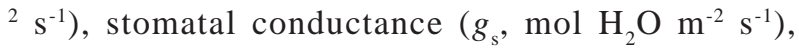
transpiration rate $\left(E\right.$, mmol $\left.\mathrm{H}_{2} \mathrm{O} \mathrm{m}^{-2} \mathrm{~s}^{-1}\right)$, intercellular $\mathrm{CO}_{2}$ concentration $\left(C_{\mathrm{i}}, \mu \mathrm{mol} \mathrm{mol}{ }^{-1}\right)$. The photosynthetically active radiation was standardized using an artificial light source at 1,000 $\mu \mathrm{mol}$ photons $\mathrm{m}^{-2} \mathrm{~s}^{-1}$ and $\mathrm{CO}_{2}$ concentration in the chamber at $420 \mathrm{ppm}$. The instantaneous water use efficiency $\left(A / E, \mu \mathrm{mol} \mathrm{mmol}{ }^{-1}\right)$, intrinsic water use efficiency $\left(A / g_{s}, \mu \mathrm{mol} \mathrm{mol}^{-1}\right)$ and the instantaneous carboxylation efficiency $\left(A / C_{\mathrm{i}}, \mathrm{mol} \mathrm{m}^{-2} \mathrm{~s}^{-1}\right)$ were estimated according to Zhang et al. (2001).

\section{Leafiness and biomass allocation in the plagiotropic branches}

The biomass allocation in the end of the maturation process was studied following a randomized block design, with three levels of number of orthotropic stems per plant (1, 2 and 3 orthotropic stems) and eight blocks. The evaluations were carried out at the harvest of 2015 and 
each experimental plot was composed of three plants cultivated in line. The previously tagged plagiotropic branches, from the photosynthetic evaluations, were collected and separated into stem, leaves and fruits.

Fully expanded leaves were randomly sampled (20 leaves per sample) to determine the average unitary leaf area (ULA, $\mathrm{cm}^{2}$ ), using an area integrator LI-3100 (Li-Cor, Inc., Lincoln, NE, USA). The total leaf area of each plagiotropic branch (PLA, $\mathrm{cm}^{2}$ ) was also evaluated, integrating the area of all leaves through the same process, in order to estimate subsequent variables. The fruits were counted to determine the number of fruits per plagiotropic branch (NFR).

Subsequently, the plant organs were dried separately, in laboratory oven with forced air circulation at $65^{\circ} \mathrm{C} \pm 2$ ${ }^{\circ} \mathrm{C}$, until the mass reached constant weight. A precision electronic scale $(0.0001 \mathrm{~g})$ was used to determine the dry mass of each plant organ: stems, leaves (LDM, g) and fruits (FDM, g). These variables, together with previously mentioned variables, were used to calculate the specific leaf area (SLA, $\left.\mathrm{cm}^{2} \mathrm{~g}^{-1}\right)$; total biomass of the plagiotropic branch (TDM, g); leaf area ratio (LAR, $\left.\mathrm{cm}^{2} \mathrm{~g}^{-1}\right)$; stem mass ratio (SMR, \%), leaf mass ratio (LMR, \%) and harvest index of plagiotropic branches (HAI, \%); the ratio of available leaf mass per fruit mass (LDM/FDM, $\mathrm{g} \mathrm{g}^{-1}$ ); the ratio of available leaf mass per fruit ( $\mathrm{LDM} / \mathrm{NFR}, \mathrm{g}$ fruit $\left.^{-1}\right)$; the ratio of leaf area per fruit mass (PLA/FDM, $\mathrm{cm}^{2} \mathrm{~g}^{-1}$ ); and the ratio of leaf area per fruit of each plagiotropic branch (PLA/NFR, $\mathrm{cm}^{2}$ fruit ${ }^{-1}$ ).

\section{Statistical analysis}

The data were submitted to analysis of variance and, in accordance to the presence of significant differences, the Tukey test was used to study the means (at $5 \%$ of probability). The analyses were performed using the statistical software Sisvar (Ferreira, 2011).

\section{RESULTS AND DISCUSSION \\ Leaf gas exchanges and photosynthetic performance}

There was no significant interaction between the effects of the number of orthotropic stems and phenological stages for the chlorophyll indexes ( $a, b$, total indexes and $a / b$ ratio), therefore, the effects of each factor were analyzed separately (Table 1). Through the individual analysis for each source of variation, it is observed that no one of the chlorophyll

Table 1: Summary of the analysis of variance for chlorophylls indexes and measurements of leaf gas exchange along the phenological stages (flowering, fruit formation and maturation) of Arabica coffee cultivated with 1, 2 and 3 orthotropic steams per plant, in Santa Teresa, Espírito Santo, Brazil, harvest 2015-16

\begin{tabular}{|c|c|c|c|c|c|c|}
\hline \multirow{2}{*}{ Parameter } & \multicolumn{6}{|c|}{ Mean square } \\
\hline & Chl $a$ & Chl $b$ & Chl $a+b$ & Chl $a / b$ & $A$ & $g_{\mathrm{s}}$ \\
\hline Block & $6.364^{\mathrm{ns}}$ & $18.027^{\mathrm{ns}}$ & $30.844^{\mathrm{ns}}$ & $0.136^{\mathrm{ns}}$ & $1.471^{\mathrm{ns}}$ & $0.00015^{\mathrm{ns}}$ \\
\hline Number of stems (P) & $0.256^{\mathrm{ns}}$ & $5.876^{\mathrm{ns}}$ & $4.476^{\mathrm{ns}}$ & $0.070^{\mathrm{ns}}$ & $9.227^{*}$ & $0.00210^{*}$ \\
\hline Residue a & 5.349 & 13.612 & 23.186 & 0.088 & 2.070 & 0.00016 \\
\hline Phenological stage (S) & $438.153^{*}$ & $1712.238^{*}$ & $3808.931^{*}$ & $1.650^{*}$ & $52.829^{*}$ & $0.02096^{*}$ \\
\hline $\mathrm{P} \times \mathrm{S}$ & $3.133^{\mathrm{ns}}$ & $18.428^{\mathrm{ns}}$ & $29.144^{\mathrm{ns}}$ & $0.036^{\mathrm{ns}}$ & $3.903^{*}$ & $0.00067^{*}$ \\
\hline Residue b & 3.461 & 12.379 & 17.887 & 0.075 & 1.453 & 0.00016 \\
\hline $\mathrm{CVa}(\%)$ & 5.20 & 12.49 & 6.51 & 19.10 & 17.08 & 27.74 \\
\hline $\mathrm{CVb}(\%)$ & 4.19 & 11.91 & 5.72 & 17.68 & 14.31 & 28.39 \\
\hline Overall mean & 44.44 & 29.55 & 73.99 & 1.50 & 8.42 & 0.04 \\
\hline \multirow{2}{*}{ Parameter } & \multicolumn{5}{|c|}{ Mean square } & \\
\hline & $E$ & $A / E$ & $A / g_{\mathrm{s}}$ & $C_{\mathrm{i}}$ & $A / C_{\mathrm{i}}$ & \\
\hline Block & $0.063^{\text {ns }}$ & $0.701^{\text {ns }}$ & $2023.16^{\mathrm{ns}}$ & $1398.76^{\mathrm{ns}}$ & $0.00009^{\text {ns }}$ & \\
\hline Number of stems (P) & $0.595^{*}$ & $0.246^{\mathrm{ns}}$ & $5433.32^{\mathrm{ns}}$ & $2167.57^{\mathrm{ns}}$ & $0.00004^{\mathrm{ns}}$ & \\
\hline Residue a & 0.084 & 2.391 & 3393.48 & 1434.44 & 0.00015 & \\
\hline Phenological stage (S) & $6.654^{*}$ & $829.029^{*}$ & $2672526.47^{*}$ & $8795.65^{*}$ & $0.00390^{*}$ & \\
\hline $\mathrm{P} \times \mathrm{S}$ & $0.261^{*}$ & $10.355^{*}$ & $25178.83^{*}$ & $236.50^{\mathrm{ns}}$ & $0.00012^{\mathrm{ns}}$ & \\
\hline Residue b & 0.082 & 1.662 & 2412.07 & 605.88 & 0.00008 & \\
\hline $\mathrm{CVa}(\%)$ & 26.81 & 15.83 & 17.40 & 22.00 & 24.32 & \\
\hline $\mathrm{CVb}(\%)$ & 26.46 & 13.20 & 14.67 & 14.30 & 18.40 & \\
\hline Overall mean & 1.08 & 9.77 & 334.65 & 172.17 & 0.05 & \\
\hline
\end{tabular}

${ }^{*}$ Significant by the F-test and ${ }^{\mathrm{ns}}$ non-significant by the F-test, at $5 \%$ of probability. Chlorophyll $a$ index $(\mathrm{Chl} a)$, chlorophyll $b$ index $(\mathrm{Chl}$ $b)$, total chlrophyll index $(\mathrm{Chl} a+b)$, chlorophyll ratio $a / b(\mathrm{Chl} a / b)$, net photosynthetic rate of $\mathrm{CO}_{2}\left(A ; \mu \mathrm{mol} \mathrm{CO}_{2} \mathrm{~m}^{-2} \mathrm{~s}^{-1}\right)$, stomatal conductance $\left(g_{\mathrm{s}} ; \mathrm{mol} \mathrm{H}_{2} \mathrm{O} \mathrm{m}^{-2} \mathrm{~s}^{-1}\right)$, transpiration rate $\left(E ; \mathrm{mmol} \mathrm{H}_{2} \mathrm{O} \mathrm{m} \mathrm{m}^{-2} \mathrm{~s}^{-1}\right)$, instantaneous water use efficiency $\left(A / E\right.$; $\left.\mu \mathrm{mol} \mathrm{mmol}^{-1}\right)$, intrinsic water use efficiency $\left(A / g_{\mathrm{s}} ; \mu \mathrm{mol} \mathrm{mol}{ }^{-1}\right)$, Intercellular $\mathrm{CO}_{2}$ concentration $\left(C_{\mathrm{i}} ; \mu \mathrm{mol} \mathrm{mol}{ }^{-1}\right)$ and instantaneous carboxylation efficiency $\left(A / C_{\mathrm{i}}\right.$; $\left.\mathrm{mol} \mathrm{m} \mathrm{m}^{-2}\right)$.

Rev. Ceres, Viçosa, v. 67, n.6, p. 454-463, nov/dec, 2020 
indexes and ratio varied with the modification of the number of orthotropic stems. However, along the phenological stages, it was observed higher index of chlorophyll $a, b$ and total during the flowering stage, and lower indexes during the fruit formation (Table 2).

The stage of fruit formation occurs in the middle of the warm season, when periods of intense heat and irradiation can cause a decrease in chlorophyll indexes due to an accelerated degradation process (Feller \& Keist, 1986). There is a considerable remobilization of reserves (mainly nitrogenous) during the grain development, being directed towards the organs with higher metabolic demand (the fruits), which may explain the decrease in the pigments of the leaves during this stage. Coffee fruits are able to drain about $95 \%$ of the total of nitrogen absorbed by the roots of the plants (Amaral et al., 2001), which justifies the great demand for this nutrient during this phenological stage. For the ratio of chlorophyll $a / b$, the highest ratios were obtained during the stages of fruit formation and maturation, which occurred due to a more pronounced decrease in the indexes of chlorophyll $b$ in relation to chlorophyll $a$, increasing the values of this ratio (Table 2). This may indicate that, during these stages, the electron transfer capacity of the antenna complex was maintained at the reaction center, in addition to serving as a photoprotective mechanism to prevent a severe photodestruction of chloroplasts (Ottander et al., 1995).

It was observed a significant effect of the interaction between the number of orthotropic stems and the phenological stages for characteristics related to photosynthesis, namely: net photosynthetic rate $(A)$, stomatal conductance $\left(g_{\mathrm{s}}\right)$, transpiration $(E)$, as well as instantaneous $(A / E)$ and intrinsic $\left(A / g_{\mathrm{s}}\right)$ water use efficiencies (Table 1).

From the fruit formation stage, there was a differentiation in the net photosynthetic rate of $\mathrm{CO}_{2}(A)$ in response to the number of orthotropic stems per plant and, in addition, it was at this stage and in plants with two orthotropic stems that largest means for $A$ were observed (Table 3). These higher rates were expected as this phenological stage is characterized by the high metabolic demand for photo-assimilates due to the development of fruits (Laviola et al., 2007).

For stomatal conductance $\left(g_{\mathrm{s}}\right)$, highest values were verified during the stages of fruit formation and maturation, especially in plants with two orthotropic stems. However, plants cultivated with three stems presented similar levels of $g_{\mathrm{s}}$ to plants with one or two orthotropic stems during the fruit formation stage (Table 3). Higher values of $g_{\mathrm{s}}$ contribute to the photosynthetic rates, as observed for plants cultivated with two stems, mainly during the stage of higher metabolic demand (fruit formation). Lower values of $g_{\mathrm{s}}$ are associated with greater

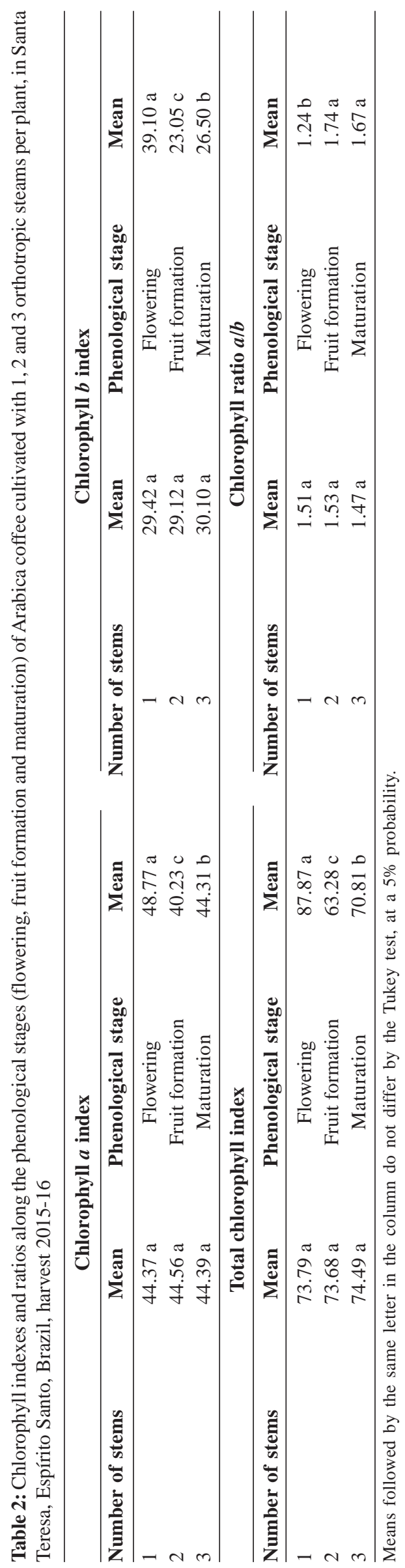

Rev. Ceres, Viçosa, v. 67, n.6, p. 454-463, nov/dec, 2020 
stomatal resistance and, consequently, with limitations to the photosynthetic rates of the coffee plants, and this limitation may cause even more preponderant effects during a period of active growth (DaMatta et al., 2008; Silva et al., 2010). In addition, low stomatal conductance may restrict the diffusion of atmospheric $\mathrm{CO}_{2}$ to the mesophyll, causing a decrease in the supply of this basic substrate for allocation at the RuBisCO (ribulose 1,5bisphosphate carboxylase oxygenase) active sites and, consequently, decrease the carboxylation rate and promote the increase of the photorespiration process, by favoring the activity of $\mathrm{RuBisCO}$ as oxigenase (Flexas et al., 2012; Martins et al., 2014).

The transpiration rates $(E)$ presented similar pattern to that observed for $g_{\mathrm{s}}$, which is expected since $E$ is directly related to the stomatal opening (Table 3 ). Thus, the greater stomatal opening promoted higher photosynthetic rates and, consequently, greater transpiration. The response regarding the number of orthotropic stems shows that coffee trees grown with two stems presented a tendency of higher leaf gas exchange rates, with beneficial results over the photosynthetic rates. This result may be caused, based on the observations described by DaMatta (2004), due to the formation of a microclimate in the new canopy configuration of these plants, which may have contributed to higher $A, g_{\text {s }}$ and $E$ values.

It is inferred that lower values of $A, g_{\mathrm{s}}$ and $E$ in plants with one orthotropic stem are attributed to a greater exposure to climatic factors, mainly high temperature and low relative humidity, which possibly caused limitations to $g_{\mathrm{s}}$ and $E$, and resulting in the decreases of $A$. In plants with three orthotropic stems, the gas exchanges rates are close to those observed in plants with one stem. These lower results can be attributed to the possible occurrence of self-shading of leaves inside the canopy, causing a limitation to the photosynthetic apparatus by a decrease in the amount of photosynthetically active radiation intercepted by the leaves in the interior of the canopy. This fact is corroborated by other studies, which affirms that coffee leaves under shading may present a decrease in the net photosynthetic rate (DaMatta, 2004; Morais et al., 2004), even with lower respiratory rates, which can contribute to achieve a positive energy balance, sufficient to meet the basic metabolism demands of the plant.

Studies report the formation of a modified microclimate in coffee plantations intercropped with shading species, causing the attenuation of climatic stresses, such as extremes of irradiation and temperature, acting as protection against environmental factors that could reduce the efficiency of physiological processes (Pezzopane et al., 2010; Partelli et al., 2014). The formation of a modified microclimate allowed the expression of greater physiological potential for $\mathrm{CO}_{2}$ fixation and better performance of the photosynthetic apparatus, besides the production of larger fruits and better organoleptic quality of the produced coffee (Bote \& Struik, 2011; Baliza et al., 2012). This same phenomenon may be partially simulated by increasing the density of coffee plantation or the density of the canopy (DaMatta et al., 2007) and, this canopy densification can be achieved by the modification of the number of the orthotropic stems per plant, as explored in the present study.

Table 3: Measurements of leaf gas exchange along the phenological stages (flowering, fruit formation and maturation) of Arabica coffee cultivated with 1, 2 and 3 orthotropic steams per plant, in Santa Teresa, Espírito Santo, Brazil, harvest 2015-16

\begin{tabular}{|c|c|c|c|c|c|c|}
\hline \multirow{2}{*}{$\begin{array}{l}\text { Number } \\
\text { of stems }\end{array}$} & \multicolumn{3}{|c|}{$A\left(\mu \mathrm{mol} \mathrm{CO} \mathrm{Cm}^{-2} \mathrm{~s}^{-1}\right)$} & \multicolumn{3}{|c|}{$g_{\mathrm{s}}\left(\mathrm{mol} \mathrm{H}_{2} \mathrm{O} \mathrm{m}^{-2} \mathrm{~s}^{-1}\right)$} \\
\hline & Flowering & Fruit formation & Maturation & Flowering & Fruit formation & Maturation \\
\hline 1 & $7.53 \mathrm{Ab}$ & $9.47 \mathrm{Ba}$ & $6.65 \mathrm{Bb}$ & $0.012 \mathrm{Ab}$ & $0.050 \mathrm{Ba}$ & $0.049 \mathrm{Ba}$ \\
\hline 2 & $7.66 \mathrm{Ab}$ & $11.31 \mathrm{Aa}$ & $8.32 \mathrm{Ab}$ & $0.010 \mathrm{Ab}$ & $0.075 \mathrm{Aa}$ & $0.080 \mathrm{Aa}$ \\
\hline 3 & $8.40 \mathrm{Aa}$ & $9.52 \mathrm{Ba}$ & $6.92 \mathrm{ABb}$ & $0.011 \mathrm{Ab}$ & $0.062 \mathrm{ABa}$ & $0.057 \mathrm{Ba}$ \\
\hline \multirow{2}{*}{$\begin{array}{l}\text { Number } \\
\text { of stems }\end{array}$} & \multicolumn{3}{|c|}{$E\left(\mathrm{mmol} \mathrm{H} \mathrm{H}_{2} \mathrm{~m}^{-2} \mathrm{~s}^{-1}\right)$} & \multicolumn{3}{|c|}{$A / E\left(\mu \mathrm{mol} \mathrm{mmol}^{-1}\right)$} \\
\hline & Flowering & Fruit formation & Maturation & Flowering & Fruit formation & Maturation \\
\hline 1 & $0.51 \mathrm{Ab}$ & $1.08 \mathrm{Ba}$ & $1.20 \mathrm{Ba}$ & $14.76 \mathrm{Ba}$ & $8.77 \mathrm{Ab}$ & $5.54 \mathrm{Ac}$ \\
\hline 2 & $0.44 \mathrm{Ac}$ & $1.47 \mathrm{Ab}$ & $1.83 \mathrm{Aa}$ & $17.41 \mathrm{Aa}$ & $7.69 \mathrm{Ab}$ & $4.55 \mathrm{Ac}$ \\
\hline \multirow[t]{6}{*}{3} & $0.50 \mathrm{Ab}$ & $1.26 \mathrm{ABa}$ & $1.43 \mathrm{Ba}$ & $16.80 \mathrm{ABa}$ & $7.55 \mathrm{Ab}$ & 4.84 Ac \\
\hline & \multirow{2}{*}{$\begin{array}{l}\text { Number } \\
\text { of stems }\end{array}$} & \multicolumn{3}{|c|}{$A / g_{\mathrm{s}}\left(\mu \mathrm{mol} \mathrm{mol}{ }^{-1}\right)$} & & \\
\hline & & Flowering & Fruit formation & Maturation & & \\
\hline & 1 & $627.5 \mathrm{Ba}$ & $189.4 \mathrm{Ab}$ & $135.7 \mathrm{Ab}$ & & \\
\hline & 2 & $766.0 \mathrm{Aa}$ & $150.8 \mathrm{Ab}$ & $104.0 \mathrm{Ab}$ & & \\
\hline & 3 & 763.6 Aa & $153.5 \mathrm{Ab}$ & $121.4 \mathrm{Ab}$ & & \\
\hline
\end{tabular}

Net photosynthetic rate of $\mathrm{CO}_{2}(A)$; stomatal conductance $\left(g_{s}\right)$; transpiration rate $(E)$; instantaneous water use efficiency $(A / E)$; intrinsic water use efficiency $\left(A / g_{s}\right)$. Means followed by the same uppercase letter in the column and lowercase letter in the row do not differ by the Tukey test, at a $5 \%$ probability.

Rev. Ceres, Viçosa, v. 67, n.6, p. 454-463, nov/dec, 2020 
Greater water use efficiency, both instantaneous $(A /$ $E)$ and intrinsic $\left(A / g_{s}\right)$, occurred at the flowering stage and for plants cultivated with two or three orthotropic stems (Table 3). These results make it possible to infer that Arabica coffee plants cultivated with two or three stems were able to assimilate more carbon per unit of transpired water, making them more efficient. This differentiation was seen in the flowering stage, possibly because it was the period in which lower variables of stomatal opening and transpiration rates were observed, but the plants were still able assimilate considerable amounts of carbon (mainly observed for plants with two and three stems). These results for water use efficiencies demonstrate that the restrictions on stomatal conductance and transpiration during the flowering stage were more intense than the restrictions over the rate of carbon assimilation, which justifies the increased efficiency.

No significant interaction was observed between the number of orthotropic stem and the phenological stage for the intercellular $\mathrm{CO}_{2}$ concentration $\left(C_{\mathrm{i}}\right)$ and the instantaneous carboxylation efficiency $\left(A / C_{\mathrm{i}}\right)$ (Table 1$)$. Studying the isolated effect of each factor, the alteration of the number of orthotropic stems per plant didn't cause significant changes over the $C_{\mathrm{i}}$ and $A / C_{\mathrm{i}}$ when (Table 4). This demonstrates that the net photosynthetic rate of carbon was compatible with the concentration of $\mathrm{CO}_{2}$ that entered the substomatic chambers regardless of the management of orthotropic stems.

As for the phenological stages, it was observed that the highest concentration of $\mathrm{CO}_{2}$ occurred during the maturation of the fruits (Table 4), which can be related to the greater degree of stomatal opening, but lower rates of carbon assimilation (Table 3), favoring the gas flow and accumulation of $\mathrm{CO}_{2}$ in the substomatic chamber. However, it was observed that the lower instantaneous carboxylation efficiency also occurred at this phenological stage (Table 4), which demonstrated that even if there was greater availability of substrate for photosynthesis $\left(\mathrm{CO}_{2}\right)$, higher fixation rates of this substrate in the photosynthetic cycle was not achieved.

\section{Leafiness and biomass allocation in the plagiotropic branches}

Through of the analysis of variance, there was no statistical difference among different numbers of orthotropic stems per plant for the unitary leaf area (ULA), the specific leaf area (SLA) and total biomass of the plagiotropic branches (TDM) (Table 5).

The development of greater leaf area per unit of dry mass of the plagiotropic branch was observed in plants cultivated with two or three orthotropic stems (Figure 1C). This is also an indication that the plants with two and three stems formed a canopy with larger leaf area for

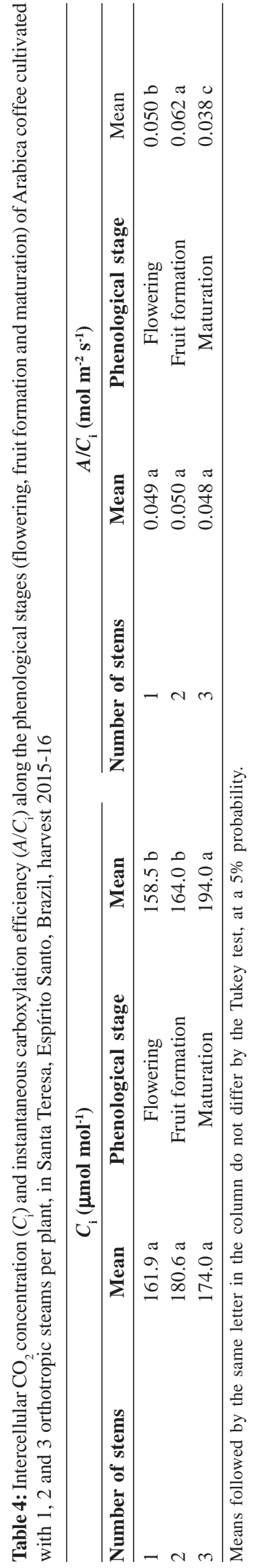

Rev. Ceres, Viçosa, v. 67, n.6, p. 454-463, nov/dec, 2020 
the interception of photosynthetic radiation, which can also increase the occurrence of self-shading due to the larger total number of branches. However, it is perceived that this morphophysiological modification was beneficial for the canopy of plants cultivated with two stems, justified by the results of leaf gas exchange rates; and, in a way, excessive and deleterious for plants with three stems, given the lower photosynthetic rates observed for these plants.

Regarding the biomass of plagiotropic branches, no statistical differentiation was observed for the TDM among plants cultivated with different numbers of orthotropic stems (Figure 1D). However, there was significant change in the mass ratios and it was possible to verify a larger allocation of dry biomass in the stems of plagiotropic branches (SMR) of plants with one and three orthotropic stems (Figure 1E); greater proportion of leaf biomass in plagiotropic branches (LMR) of plants with two or three orthotropic stems (Figure 1F); and higher proportion of biomass allocated in the fruits (HAI) for plants with one single vertical stem (Figure 1G). This latter result can be used to explain the occurrence of depletion in plants with one orthotropic stem, as result from the exhaustion of the plant in order to sustain the demand of a large proportion of fruits in relation to the development of the rest of the plagiotropic branch. This depletion is caused by the increased strength of the main metabolic sink (high HAI) and decrease of the tissues that are metabolic source (LMR). Based on these results, it can be observed that the plants with one stem presented greater investment to accumulate biomass on the fruits, whereas plants with two and three vertical stems invested relatively more in the growth of their leaves, however, keeping the overall fruit production of the coffee tree due to the larger number of branches available to sustain it. Almeida (2015) also found higher HAI and lower LMR and SMR in plant of Arabica coffee due to the increase in plant spacing, as well as a decrease in the leaf area ratio available to sustain the formation of fruits. This author correlated these results with the possible decrease of the longevity of the coffee crop, as well as the increase effect of the bienniality.

Plants cultivated with two or three orthotropic stems presented larger leafiness available to sustain the production of fruits, independently of the studied parameter (Figure 2A, 2B, 2C, 2D). Thus, the management of the plants with more than one orthotropic stem was able to condition the plants to produce fruits without exhausting the organs which are sources of photoassimilates (leaves), presenting overall greater quantity, area and proportion of these organs. Because of this behavior, it is less likely that plants with two or three orthotropic stems will suffer depletion to the point of compromising the productivity of the next reproductive cycle. All this leads to the assumption that the crop bienniality should be less pronounced in plants with two or three orthotropic stems, due to their results for leaf/ fruit ratio, growth and leaf gas exchange rates. Rodrigues et al. (2016) reported the relationship between lesser biennial effects and larger leaf areas available for fruit

Table 5: Summary of the analysis of variance for leafiness and biomass allocation in the plagiotropic branches of Arabica coffee cultivated with 1, 2 and 3 orthotropic steams per plant, in the phenological stages of fruit maturation, in Santa Teresa, Espírito Santo, Brazil, harvest 2015-16

\begin{tabular}{|c|c|c|c|c|c|c|}
\hline \multirow{2}{*}{ Parameter } & \multicolumn{6}{|c|}{ Mean square } \\
\hline & ULA & SLA & LAR & TDM & SMR & LMR \\
\hline Block & $109.25^{\text {ns }}$ & $168.03^{\mathrm{ns}}$ & $5.08^{\mathrm{ns}}$ & $15.66^{\mathrm{ns}}$ & $0.45^{\text {ns }}$ & $6.55^{*}$ \\
\hline Number of stems & $46.87^{\mathrm{ns}}$ & $269.01^{\mathrm{ns}}$ & $80.86^{*}$ & $91.21^{\mathrm{ns}}$ & $6.61^{*}$ & $36.62^{*}$ \\
\hline Residue & 65.58 & 107.73 & 4.42 & 53.22 & 1.12 & 1.77 \\
\hline $\mathrm{CV}(\%)$ & 18.83 & 8.65 & 13.70 & 16.41 & 7.92 & 10.41 \\
\hline Overall mean & 43.00 & 120.03 & 15.34 & 44.44 & 13.37 & 12.79 \\
\hline \multirow{2}{*}{ Parameter } & \multicolumn{5}{|c|}{ Mean square } & \\
\hline & HAI & PLA/FDM & PLA/NFR & LDM/FDM & LDM/NFR & \\
\hline Block & $7.20^{*}$ & $14.54^{\mathrm{ns}}$ & $1.96^{\mathrm{ns}}$ & $0.0016^{*}$ & $0.0004^{\mathrm{ns}}$ & \\
\hline Number of stems & $21.55^{*}$ & $172.59^{*}$ & $41.88^{*}$ & $0.0081^{*}$ & $0.0019^{*}$ & \\
\hline Residue & 1.66 & 10.20 & 1.76 & 0.0004 & 0.0001 & \\
\hline $\mathrm{CV}(\%)$ & 1.75 & 15.28 & 14.56 & 11.52 & 16.08 & \\
\hline Overall mean & 73.84 & 20.90 & 9.13 & 0.17 & 0.08 & \\
\hline
\end{tabular}

${ }^{*}$ Significant by the F-test and ${ }^{\mathrm{ns}}$ non-significant by the F-test, at $5 \%$ of probability. Unitary leaf area $\left(\mathrm{ULA}\right.$; $\left.\mathrm{cm}^{2}\right)$, specific leaf area $(\mathrm{SLA}$; $\mathrm{cm}^{2} \mathrm{~g}^{-1}$ ), leaf area ratio (LAR; $\mathrm{cm}^{2} \mathrm{~g}^{-1}$ ), total biomass of the plagiotropic branch (TDM; g), stem mass ratio (SMR; \%), leaf mass ratio (LMR; $\%$ ), harvest index of plagiotropic branches (HAI; \%), ratio of available leaf area per fruit mass (PLA/FDM; $\mathrm{cm}^{2} \mathrm{~g}^{-1}$ ), ratio of available leaf area per fruit of each plagiotropic branch (PLA/NFR; $\mathrm{cm}^{2}$ fruit ${ }^{-1}$ ), ratio of available leaf mass per fruit mass $\left(\mathrm{LDM} / \mathrm{FDM}\right.$; $\left.\mathrm{g}^{-1}\right)$ and the ratio of available leaf mass per fruit (LDM/NFR; $g$ fruit $\left.{ }^{-1}\right)$. 
formation, studying several genotypes of Arabica coffee subjected to the densification of the crop.

The lower leaf/fruit ratio indicates a prioritization of the development of fruits in detriment of the development of vegetative structures, mainly due to the fact that fruits are stronger metabolic sinks (Chaves et al., 2012). This behavior often leads to a negative effect over the yield of the subsequent cycle. This probable impoverishment contributes greatly to the development of biennial production cycles (DaMatta et al., 2007).

It has been reported that a leaf/fruit ratio of about 20 $\mathrm{cm}^{2}$ of leaf area is required to support the adequate formation of a fruit, without restricting the vegetative growth (Cannell, 1985). However, for highly productive genotypes, which form plants with large numbers of fruits, this relationship may be considerably lower (DaMatta et al., 2008). In these conditions, the stimuli of the fruits formation increases the photosynthetic rates, as observed for coffee plants subjected to manipulation of their leafiness (DaMatta et al., 2008).

It is believed that in field conditions, this increase in photosynthetic rates occurs to support the demand for photo-assimilates of the growing fruits, when the leaf/ fruit ratio is lower (DaMatta et al., 2008), as observed for treatments with two and three orthotropic stems (higher $A$ rates and values of PLA/NFR values below $20 \mathrm{~cm}^{2}$ per fruit). It is possible that these lower values of PLA/NFR were supplied by the increases in leaf gas exchange and did not cause detrimental effects over to vegetative growth.
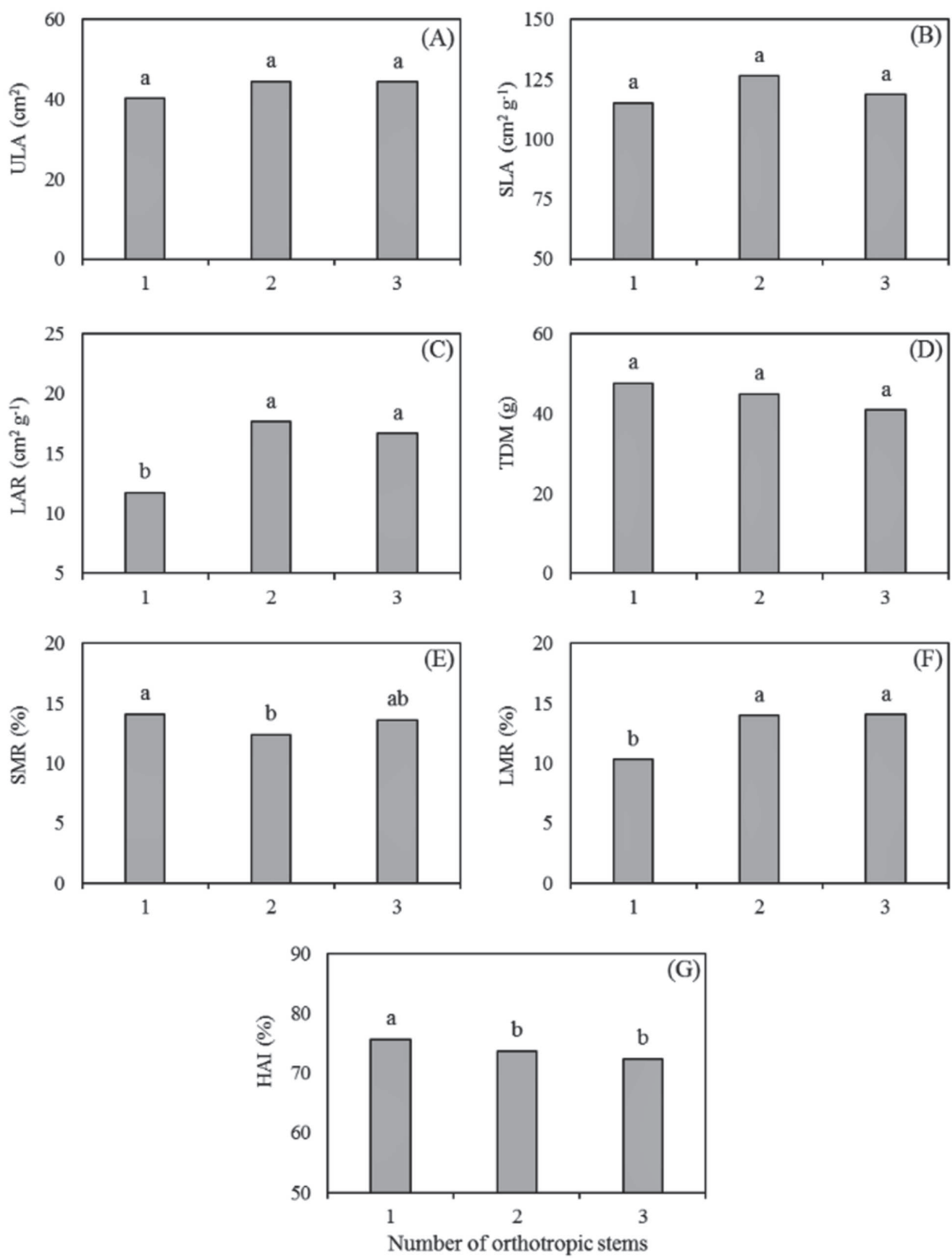

Figure 1: Unitary leaf area (A), specific leaf area (B), leaf area ratio (C), total dry matter of plagiotropic branches (D), stem mass ratio (E), leaf mass ratio (F), and harvest index $(\mathrm{G})$ of plants of Arabica coffee cultivated with 1, 2 and 3 orthotropic steams, in Santa Teresa, Espírito Santo, Brazil, harvest 2015-16 (Bars topped by the same letter do not differ by the Tukey test, at a 5\% probability). 

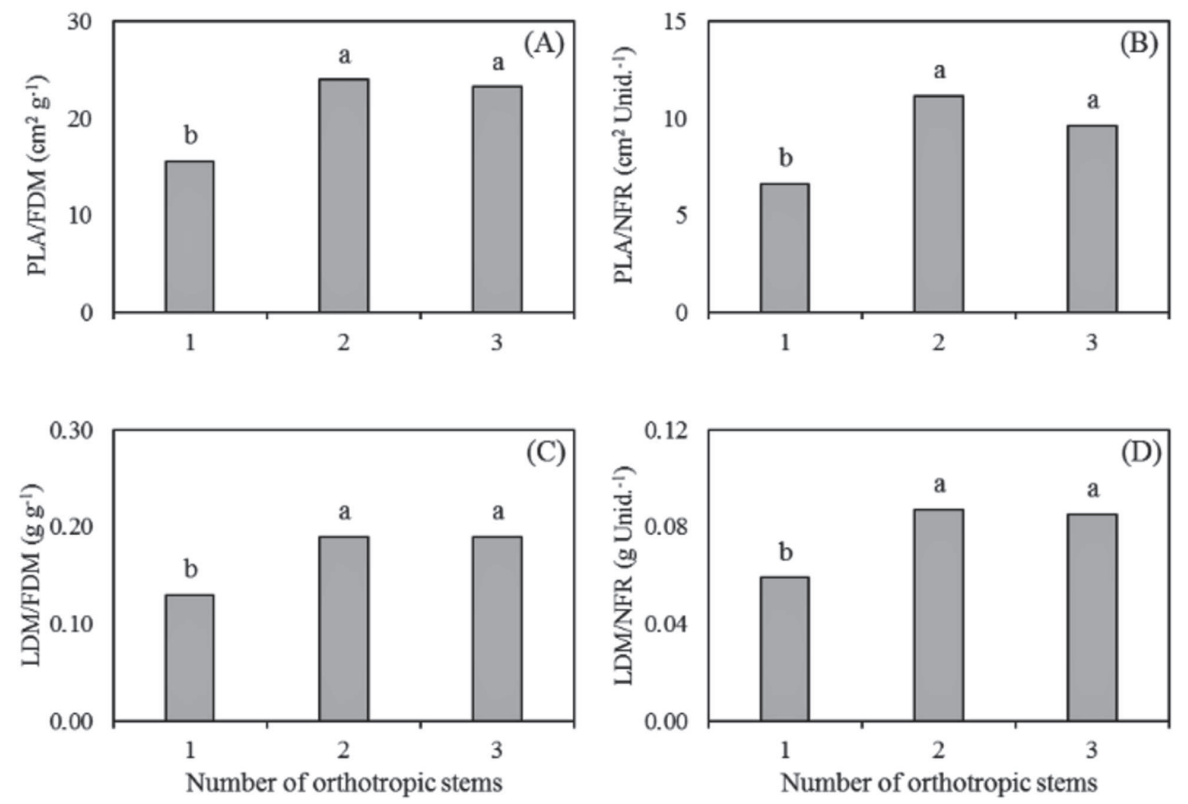

Figure 2: Ratios of leaf area per fruit mass (A), leaf area per fruit (B), leaf mass per fruit mass (C), and leaf mass per fruit (D) of plants of Arabica coffee cultivated with 1, 2 and 3 orthotropic steams, in Santa Teresa, Espírito Santo, Brazil, harvest 2015-16 (Bars topped by the same letter do not differ by the Tukey test, at a 5\% probability).

However, for plants conducted with one single orthotropic stem, the decrease in the PLA/NFR ratio was more pronounced, and no increase in the photosynthetic rates was observed. This condition can considerably compromise the vegetative growth, due to the competition with the fruits for photo-assimilates, which creates a condition that favors the plant depletion. Chaves et al. (2012) reported that decreasing the ratio between the leaf area and the number of fruits of the plagiotropic branches caused a decrease in the growth and fruit production, also causing increase in the occurrence of death of plagiotropic branches, which may be evidence of excessive competition between vegetative and reproductive growth.

An adequate relation between leaves and fruits is desirable to the sustainability of the crop, allowing the coffee trees to be capable of sufficiently supplying the metabolic demands of fruits and vegetative structures alike and, thus, support high yields (Alves, 2008). Otherwise, if there is not a considerable increment in the leaf area until the end of the fruit formation, the competition between vegetative and reproductive growth may enhance the negative effects of biennial production cycles (Laviola et al., 2007).

It is worth mentioning that Catuaí cultivars may exhibit early depletion due to the high metabolic demand of their high fruit loads (Alves, 2008). This characteristic may had been minimized due to the stem management used in this study, as demonstrated by the results obtained using more than one orthotropic stem per plant.

\section{CONCLUSIONS}

The management with more orthotropic stems per plant of Arabica coffee is capable of promoting the photosynthetic rates and modulating the allocation of biomass destined to each organ.

Cultivating the plants of Arabica coffee with two orthotropic stems, under the studied conditions, creates conditions which may promote the photosynthetic rates.

The management of the Arabica coffee with more than one stem promotes an increase in the proportion of leaves available in relation to the amount of fruit to be exported, which makes it possible to sustain the production of fruits with less metabolic wearing.

\section{ACKNOWLEDGEMENTS, FINANCIAL SUPPORT AND FULL DISCLOSURE}

The authors would like to thank the Centro de Ciências Agrárias e Engenharias of the Universidade Federal do Espírito Santo (CCAE-UFES) for providing support and access to the laboratory, equipment and facilities. Also, to the Instituto Capixaba de Pesquisa, Assistência Técnica e Extensão Rural (INCAPER), for the partnership to develop this research.

The authors declare no conflicts of interest in carrying out this research and publishing this manuscript.

\section{REFERENCES}

Almeida WL (2015) Respostas morfofisiológicas e de produtividade de cultivares de Coffea arabica L. em função da variação do espaçamento na linha de plantio. Dissertação de Mestrado. Universidade Federal de Viçosa, Rio Paranaíba. 44p. 
Alves JD (2008) Morfologia do cafeeiro. In: Carvalho CHS (Ed.) Cultivares de café: origem, características e recomendações. Brasília, Embrapa Café. p.35-57.

Amaral JAT, DaMatta FM \& Rena AB (2001) Effects of fruiting on the growth of Arabica coffee trees as related to carbohydrate and nitrogen status and nitrate reductase activity. Brazilian Journal of Plant Physiology, 13:66-74.

Baliza DP, Cunha RL, Guimarães RJ, Barbosa JPRAD, Avila FW \& Passos AMA (2012) Physiological characteristics and development of coffee plants under different shading levels. Revista Brasileira de Ciências Agrárias, 7:37-43.

Bote ADE \& Struik PC (2011) Effects of shade on growth, production and quality of coffee (Coffea arabica) in Ethiopia. Journal of Horticulture and Forestry, 3:336-341.

Camargo AP \& Camargo MBP (2001) Definição e esquematização das fases fenológicas do cafeeiro arábica nas condições tropicais do Brasil. Bragantia, 60:65-68.

Cannell MG (1985) Physiology of the coffee crop. In: Clifford MN \& Willson KC (Ed.) Coffee: Botany, Biochemistry and Production of Beans and Beverage. London, Crom Helm. p.108134

Carvalho CHM, Colombo A, Scalco MS \& Morais AR (2006) Evolução do crescimento do cafeeiro (Coffea arabica L.) irrigado e não irrigado em duas densidades de plantio. Ciência e Agrotecnologia, 30:243-250.

Chaves ARM, Martins SC, Batista KD, Celin EF \& DaMatta FM (2012) Varying leaf-to-fruit ratios affect branch growth and dieback, with little to no effect on photosynthesis, carbohydrate or mineral pools, in different canopy positions of field-grown coffee trees. Environmental and Experimental Botany, 77:207218

Colodetti TV, Tomaz MA, Rodrigues WN, Verdin Filho AC, Cavatte PC \& Reis EF (2018) Arquitetura da copa do cafeeiro arábica conduzido com diferentes números de ramos ortotrópicos. Revista Ceres, 65:415-423.

DaMatta FM (2004) Ecophysiological constraints on the production of shaded and unshaded coffee: a review. Field Crops Research, 86:99-114.

DaMatta FM, Cunha RL, Antunes WC, Martins SCV, Araujo WL, Fernie AR \& Moraes GABK (2008) In field grown coffee trees source-sink manipulation alters photosynthetic rates, independently of carbon metabolism, via alterations in stomatal function. New Phytologist, 178:348-357.

DaMatta FM, Ronchi CP, Maestri M \& Barros RS (2007) Ecophysiology of coffee growth and production. Brazilian Journal of Plant Physiology, 19:485-510.

Feller U \& Keist M (1986) Senescence and nitrogen metabolism in annual plants. In: Lambers H, Neeteson JJ \& Stulen I (Ed.) Fundamental, ecological and agricultural aspects of nitrogen metabolism in higher plants. Dordrecht, Martinus Nijhoff. p.219234 .

Ferreira DF (2011) SISVAR: A Computer statistical Analysis System. Ciência e Agrotecnologia, 35:1039-1042.

Flexas J, Barbour MM, Brendel O, Cabrera HM, Carriquí M, DíazEspejo A, Douthe C, Dreyer E, Ferrio JP, Gago J, Gallé A, Galmés J, Kodama N, Medrano H, Niinemets Ü, Peguero-Pina JJ, Pou A, Ribas-Carbó M, Tomás M, Tosens T \& Warren CR (2012) Mesophyll diffusion conductance to $\mathrm{CO}_{2}$ : an unappreciated central player in photosynthesis. Plant Science, 193-194:70-84.
Laviola BG, Martinez HEP, Salomão LCC, Cruz CD, Mendonça SM \& Neto AP (2007) Alocação de fotoassimilados em folhas e frutos de cafeeiro cultivado em duas altitudes. Pesquisa Agropecuária Brasileira, 42:1521-1530.

Martins SCV, Galmés J, Cavatte PC, Pereira LF, Ventrella MC \& DaMatta FM (2014) Understanding the low photosynthetic rates of sun and shade coffee leaves: bridging the gap on the relative roles of hydraulic, diffusive and biochemical constraints to photosynthesis. Plos One, 9:01-10.

Morais H, Medri ME, Marur CJ, Caramori PH, Ribeiro AMA \& Gomes JC (2004) Modifications on leaf anatomy of Coffea arabica caused by shade of pigeonpea (Cajanus cajan). Brazilian Archives of Biology and Technology, 47:863-871.

Ottander C, Campbell D \& Öquist G (1995) Seasonal changes in photosystem II organization and pigment composition in Pinus sylvestris. Planta, 197:176-183.

Partelli FL, Araújo AV, Vieira HD, Dias JRM, Menezes LFT \& Ramalho JC (2014) Microclimate and development of 'Conilon' coffee intercropped with rubber trees. Pesquisa Agropecuária Brasileira, 49:872-881.

Pereira SP, Baliza DP, Santos MO, Alves JD \& Guimarães RJ (2013) Influência do espaçamento de cultivo em duas épocas de poda nos teores caulinares de carboidratos em cafeeiros. Coffee Science, 8:460-468.

Pezzopane JEM, Castro FS, Pezzopane JRM \& Cecílio RA (2012) Agrometeorologia: aplicações para o Espírito Santo. Alegre, CAUFES. $174 \mathrm{p}$.

Pezzopane JRM, Marsetti MMS, Souza JM \& Pezzopane JEM (2010) Condições microclimáticas em cultivo de café conilon a pleno sol e arborizado com nogueira macadâmia. Ciência Rural, 40:01-07.

Prezotti LC, Gomes JA, Dadalto GG \& Oliveira JA (2007) Manual de recomendação de calagem e adubação para o Estado do Espírito Santo: $5^{\mathrm{a}}$ aproximação. Vitória, SEEA/INCAPER/ CEDAGRO. 305p.

Reis PR \& Cunha RL (2010) Café arábica: do plantio à colheita. Lavras, Epamig. 896p.

Rodrigues WN, Tomaz MA, Ferrão MAG, Martins LD, Colodetti TV, Brinate SVB, Amaral JFT, Sobreira FM \& Apostólico MA (2016) Biometry and diversity of Arabica coffee genotypes cultivated in a high density plant system. Genetics and Molecular Research, 15:01-12.

Sartori IA, Koller OC, Theisen S, Souza PVD, Bender RJ \& Marodin GAB (2007) Efeito da poda, raleio de frutos e uso de fitorreguladores na produção de tangerineiras (Citrus deliciosa Tenore) cv. Montenegrina. Revista Brasileira de Fruticultura, 29:05-10

Silva L, Marchiori PER, Maciel CP, Machado EC \& Ribeiro RV (2010) Fotossíntese, relações hídricas e crescimento de cafeeiros jovens em relação à disponibilidade de fósforo. Pesquisa Agropecuária Brasileira, 45:965-972.

Verdin Filho AC, Volpi PS, Ferrão MAG, Ferrão RG, Mauri AL, Fonseca AFA, Tristão FA \& Andrade Júnior S (2016) New management technology for Arabica coffee: the cyclic pruning program for arabica coffee. Coffee Science, 11:475-483.

Zhang S, Li Q, Ma K \& Chen L (2001) Temperature-dependent gas exchange and stomatal/non-stomatal limitation to $\mathrm{CO}_{2}$ assimilation of Quercus liaotungensis under midday high irradiance. Photosynthetica, 39:383-388. 